\title{
Entrepreneur-related Constructs Explaining the Emergence of Born Global Firms: A Systematic Literature Review
}

\author{
Elena Pawęta
}

\begin{abstract}
A B S T R A C T
Objective: The paper is aimed at structuring entrepreneur-related constructs and building a conceptual framework that can serve as a foundation for future international entrepreneurship research and theory building.

Research Design \& Methods: The author conducted the systematic literature review of 94 empirical studies and conceptual papers on the entrepreneur-related determinants of early internationalisation in the international management journals in the years 1966 $-2015$.
\end{abstract}

Findings: This article discusses and groups the existing knowledge on entrepreneurrelated determinants of born globals successful international performance. The major theoretical contribution of the study is the conceptual framework of the main entrepreneur-level determinants of rapid internationalisation.

Implications \& Recommendations: The results of the study are exploratory and there is a need in validating the theoretical framework through an advanced quantitative study. Future research might try to integrate the reviewed entrepreneur-related constructs with organisational characteristics and external characteristics which determine born globals emergence.

Contribution \& Value Added: This paper provides the conceptual framework that groups entrepreneur-related constructs into 6 main categories which can enrich future international entrepreneurship research.

\begin{tabular}{ll}
\hline Article type: & literature review \\
Keywords: & born globals; international entrepreneurship; internationalisation \\
JEL codes: & F23
\end{tabular}

Received: 15 September 2015 Revised: 18 November 2015 Accepted: 16 December 2015

\section{Suggested citation:}

Pawęta, E. (2015). Entrepreneur-Related Constructs Explaining the Emergence of Born Global Firms: A Systematic Literature Review. Entrepreneurial Business and Economics Review, 3(4), 11-36. doi: 10.15678/EBER.2015.030402 


\section{INTRODUCTION}

Research on international business in the 20th century has been mostly focused on large multinational companies. Management of small and medium-sized enterprises (SMEs) and venture creation was rather the topic of interest for entrepreneurship scholars (McDougall \& Oviatt, 2000). However, in the end of 20th century, the research borders between international business and entrepreneurship started to vanish. Due to changing global business environment - more efficient communication technology and transportation, decrease in governmental protectionism and increasing opportunities to get international experience - it became less costly to conduct business activities in different countries. This contributed to the emergence of the international entrepreneurship phenomenon (McDougall \& Oviatt, 2000; Zahra \& George, 2002).

International entrepreneurship concept, which combines elements of international business theory and entrepreneurship theory, is devoted to the new ways of firms' internationalisation. The traditional stage model of internationalisation (Johanson \& Wiederheim-Paul, 1975; Johanson \& Vahlne, 1977) understood it as a slow process with several consecutive stages. However, new competitive environment, empowered by globalisation and integration processes, showed that stage theory cannot be applied anymore and new models are needed to explain the way SMEs internationalise. Starting from the early 1990s studies on the theory of international entrepreneurship focused on SMEs which enter international markets immediately after their emergence (McDougall, 1989; Rennie, 1993; Oviatt \& McDougall, 1994). Those companies, called born globals (Knight \& Cavusgil, 1996; Madsen \& Servais, 1997) or international new ventures (McDougall et al., 1994) do not use traditional incremental methods of exporting and begin to export from the first days of their existence.

The researchers have been trying to explain the key drivers of international expansion that are key for born global companies (Knight, 2000; Zahra \& George, 2002). Most of the studies show the combination of external factors, internal factors and factors related to the entrepreneur who pushes companies to go global (Zahra \& George, 2002). External factors are mainly associated with the market characteristics, as sectoral or regional export culture, international trade incentives or demand characteristics. Internal, organisational reasons of going international are niche products, global strategy and resource availability. Entrepreneur-related reasons, however, are found to be fundamental in the internationalisation of a company. Those reasons are usually associated with: (1) capabilities and aspirations of an entrepreneur before starting the business (Covin \& Slevin, 1989; Knight, 2000; Andersson \& Wictor, 2003) or (2) with entrepreneur's way of thinking and making decisions in the process of internationalisation (Harms \& Schiele, 2012; Sarasvathy et al., 2014).

Those entrepreneur-related constructs are often overlapping and often it is difficult to distinguish among them, in consequence there are also some confusions within the international entrepreneurship literature. Therefore, there is a need for structuring entrepreneur-related constructs and building an integrative framework that could serve as a foundation for future international entrepreneurship research. 
This paper aims to analyse and systematise the existing knowledge on the entrepreneur-related determinants of successful international performance of born global companies through the systematic literature review of empirical studies in the international management journals in the years 1966 - 2015. The following section describes methodology used for conducting the research. The next sections present analysis and findings - key constructs emerging in the literature and proposition of a theoretical framework. Finally, conclusions and directions for the future research are presented.

\section{MATERIAL AND METHODS}

The systematic literature review was carried out in order to identify the current state of knowledge on the main entrepreneur-related factors which influence rapid internationalisation. It was carried out through a systematic analysis of 94 articles mostly from the leading scientific journals, but also from regional journals, monograph chapters and conference proceedings. The articles reviewed were published in the years 1966-2015. However, the majority of them (73) come from the 21st century. A three-stage procedure was used to select the articles:

1. using online bibliographic database Web of Science which provides access to the main international scientific journals in the fields of social sciences, art and humanities (the following keywords in different combinations were used for the search: "born global", "internationalisation", "determinants of internationalisation", "entrepreneurial orientation", "effectuation");

2. analysing references of the articles found, with a special regard to literature reviews and conceptual papers bibliography;

3. screening the articles in order to access their relevance to the research and select the final sample.

After the first two stages of research, 132 articles on internationalisation were identified. Papers reviewed ranged from the general conceptual papers concerning international marketing and international entrepreneurship to specific publication analysing a certain industry or a certain region. However, after the thorough examination, 38 of them were eliminated from the list as they were not relevant for the aims of this research. The remaining 94 articles were included into the final sample for the systematic literature review. They could be categorised into two main groups (with the dominance of the first one):

- empirical research on internationalisation of SMEs, especially with the focus on the entrepreneur-related determinants of internationalisation;

- conceptual papers or literature reviews which have an important contribution to the development of the international entrepreneurship science

The selected articles were published in 41 scientific journals, conference proceedings or monographs. Table 1 shows the most represented journals in the conducted review most of the articles reviewed belong to the leading scientific management journals like Journal of International Business Studies (11 articles), Journal of International Marketing (11 articles), Journal of International Entrepreneurship (8 articles), Journal of World Business (7 articles), International Business Review (7 articles). 
The review of the internationalisation literature was aimed at determining the topic and main objectives of the research, the research methodology adopted, the country of origin of the study and the key findings. Appendix 1 contains a sample of works on internationalisation from the past decades starting from acknowledged article by Vernon (1966) and a key work from the Uppsala University (Johanson \& Vahlne, 1977). The process of reviewing and analysing was hindered by the diversity of writing and publishing styles, which can be observed in the articles from different timespans and different journals.

Table 1. The list of the most represented journals in literature review

\begin{tabular}{|l|c|}
\hline \multicolumn{1}{|c|}{ Journal } & Number of articles \\
\hline Journal of International Business Studies & 11 \\
\hline Journal of International Marketing & 11 \\
\hline Journal of International Entrepreneurship & 8 \\
\hline Journal of World Business & 7 \\
\hline International Business Review & 7 \\
\hline Academy of Management Journal & 4 \\
\hline International Marketing Review & 4 \\
\hline Entrepreneurship: Theory and Practice & 3 \\
\hline Strategic Management Journal & 3 \\
\hline Journal of Business Venturing & 2 \\
\hline Management Science & 2 \\
\hline Small Business Economics & 2 \\
\hline Management International Review & 2 \\
\hline
\end{tabular}

Source: own study.

Main methodological aspects and key findings of the articles selected are presented in Appendix 1. It reveals the following information on the reviewed papers:

1. Authors of the article and the year of publication;

2. Sample characteristics - number of the companies, industry in which they operate, size of firms analysed;

3. Country of origin of the study;

4. Methodology used in the study - qualitative, quantitative, mixed, literature review or conceptual paper;

5. Key findings in terms of entrepreneur-related characteristics which determine rapid internationalisation or related topics.

The main constructs which emerged from the literature review are presented and discussed in the next section.

\section{FINDINGS}

The systematic literature review based on the presented methodology revealed that the topic of individual level factors influencing internationalisation is widely discussed in the international business literature. The research methodologies used, sample sizes and context of the analysis depicted in Figure 1 highlight balance within the international entrepreneurship research methods - there are 27 qualitative studies, 32 quantitative studies, 
21 conceptual papers, 9 papers using mixed research methods (qualitative and quantitative) and 5 literature reviews. Quantitative papers dominate in the internationalisation literature, although qualitative research methods, conceptual papers and literature reviews are also well represented. Empirical studies however do not tend to use a longitudinal cross-cultural approach, but focus on a specific region or specific industry and analysis tends to be short-term. The countries of origin of the studies differ significantly, what indicates the widespread research on rapid internationalisation. Nevertheless, the majority of papers come from North America and the Nordic Countries.

Analysis of entrepreneur-related constructs within the internationalisation process has revealed several research fields, which are partially overlapping. The main constructs relevant to the topic reviewed are: (1) innovation and technology orientation, (2) entrepreneurial/managerial knowledge, (3) entrepreneurial orientation, (4) effectuation logic, (5) international networks and (6) dynamic capabilities. Table 2 demonstrates the meaning of those constructs and their application in prior studies.

\section{Innovation and technology}

Among the key factors determining internationalisation, innovation and technology orientation is often observed. In one of the early empirical studies on born global firms, Rennie (1993) noticed that almost half of the surveyed companies ranked technology as their most critical lever. There is an empirical evidence that in response to globalisation SMEs tend to put greater emphasis on acquiring technology in order to prepare in advance before entering foreign markets (Knight, 2000; Knight \& Cavusgil, 2004). Some studies (Jones, 2001; Luostarinen \& Gabrielsson, 2004) find that although managers of born global companies are young and inexperienced when it comes to international business, they are often technologically competent. Especially, it is the case for high-technology companies or firms from IT sector.

\section{Entrepreneurial and managerial knowledge}

Born global researchers pay much attention to the international experience and prior knowledge of an entrepreneur. There is some evidence that born global entrepreneur's international living and work experience and his or her education are the factors which push them towards global markets (Madsen \& Servais, 1997; Chetty \& Campbell-Hunt, 2004). It is explained by the fact that prior knowledge and work experience reduce the psychic distance to global markets and minimize uncertainty. Chetty \& Campbell-Hunt (2004) even hypothesize that present-day managers of born global firms are better educated than the generation of managers in 1977 when the stage internationalisation model was presented. Prior international experience of an entrepreneur plays an important role in increasing the firm's speed of learning and internationalisation (Oviatt \& McDougall, 1997).

Researchers (Sapienza et al., 2006; Brennan \& Garvey, 2009) suggest that the managers' previous international experience influences the outcomes of internationalisation because it may substitute for the lack of organisational experience with internationalisation. They state that internationalisation knowledge is already accumulated in the company through individual entrepreneurs who found the company.

\section{Entrepreneurial orientation}

Entrepreneurial orientation construct is associated with a strong leader who initiates 
Table 1. Entrepreneur-related constructs in the prior studies and findings on early internationalisation

\begin{tabular}{|c|c|c|}
\hline Construct & Meaning & Supporting references \\
\hline $\begin{array}{l}\text { Effectuation } \\
\text { logic }\end{array}$ & $\begin{array}{l}\text { Effectuation is a decision-making behaviour, which is } \\
\text { employed under uncertainty, when future is unpredictable } \\
\text { and goals are not clearly known. Effectual thinking includes } \\
\text { considering the available means, keeping in mind what is } \\
\text { affordable to lose, then seeking for strategic partnerships } \\
\text { and exploiting contingencies to control the unpredictable } \\
\text { future. }\end{array}$ & $\begin{array}{l}\text { Chandra et al. (2009); Bhowmick (2008); Mainela \& Puhakka (2008); } \\
\text { Schweizer et al. (2010); Andersson (2011); Harms \& Schiele (2012); } \\
\text { Sarasvathy et al. (2014); Gabrielsson \& Gabrielsson (2013); Galkina \& Chetty } \\
\text { (2015) }\end{array}$ \\
\hline $\begin{array}{l}\text { International } \\
\text { networks }\end{array}$ & $\begin{array}{l}\text { Personal international networks of an entrepreneur help to } \\
\text { find opportunities and to internationalise. Dealing with } \\
\text { network partners for a company helps to supplement } \\
\text { internal capabilities, for example to recruit workers with } \\
\text { previous experience in the industry. }\end{array}$ & $\begin{array}{l}\text { Forsgren (1989); Johanson \& Vahlne (1990); Coviello \& Munro (1997); } \\
\text { Keeble et al. (1998); McAuley (1999); Andersson \& Wictor (2003); Sharma \& } \\
\text { Blomstermo (2003); Moen et al. (2004); Andersson (2004); Freeman et al. } \\
\text { (2006); Loane (2007); Laanti et al. (2007); Rutihinda (2008); Gabrielsson et } \\
\text { al. (2008); Chandra et al. (2009); Zhang et al. (2009); Crick \& Crick (2014); } \\
\text { Laurell et al. (2013) }\end{array}$ \\
\hline $\begin{array}{l}\text { Dynamic } \\
\text { capabilities }\end{array}$ & $\begin{array}{l}\text { Dynamic capabilities are the strategic routines by which } \\
\text { ventures achieve new resources configurations. They are } \\
\text { the drivers behind the creation of new resources and new } \\
\text { sources of competitive advantage. }\end{array}$ & $\begin{array}{l}\text { Madsen \& Servais (1997); Eisenhardt \& Martin (2000); Lu \& Beamish (2001); } \\
\text { King \& Tucci (2002); Jantunenet al. (2005); Sapienza et al. (2006); } \\
\text { Gassmann \& Keupp (2007); Laanti et al. (2007); Weerawardena } \\
\text { et al. (2007); Pranger \& Verdier (2011) }\end{array}$ \\
\hline
\end{tabular}

Source: own study. 
innovativeness, proactiveness and risk taking (Knight, 2000). Firms with an entrepreneurial orientation pioneer in innovative products/ markets, engage in risky ventures and are characterised by decision action. Furthermore, according to Lumpkin and Dess (1996), such companies also combine autonomy and competitive aggressiveness, where autonomy means independent action of a person or team in giving birth to an idea, and competitive aggressiveness refers to firm's tendency to outperform in the marketplace and intensively challenge competitors.

Studies on rapid internationalisation agree that born global firms tend to possess certain characteristics as management team with "unusual constellation of competencies" (McDougall et al., 1994). It has been supported by empirical research that entrepreneurial orientation has a significant effect on international performance of companies. Entrepreneurial orientation is associated with quality leadership in born global companies (Knight, 2000; Jantunen et al., 2005; Kuivalainen et al., 2002). Researchers agree that possession of an entrepreneurial orientation is important in the development of company's strategy. Jantunen et al. (2005) state that the issue of entrepreneurial orientation within the internationalisation context is a relevant and under-researched topic, and suggest that entrepreneurial orientation might have a positive effect on international performance.

\section{Effectuation logic}

There are several studies which connect international orientation of companies to the effectual way of thinking (Bhowmick, 2008; Mainela \& Puhakka, 2008; Schweizer, Vahlne, \& Johansson, 2010; Sarasvathy et al., 2014; Galkina \& Chetty, 2015). A theory of effectuation, entrepreneurial way of thinking and making decisions under uncertainty, was first introduced in 2001 by Saras Sarasvathy. She described two distinct types of logic used in decision-making processes - causation and effectuation. Causation refers to the typical managerial rational behaviour, where decisions are based on searching the ways to reach a distinct goal. Causation consists of starting with a given goal, then focusing on expected returns and competitive analysis and finally assembling means to achieve the given goal. Effectuation includes a set of decision-making behaviours, which are employed in the situations of uncertainty, when future is unpredictable, goals are not clearly known and there is no independent environment that serves as the ultimate selection mechanism. Effectual thinking includes considering the available means, keeping in mind what is affordable to lose, then seeking for strategic partnerships and exploiting contingencies to control the unpredictable future (Sarasvathy, 2001). According to Sarasvathy, effectual thinking is the prevailing logic among expert entrepreneurs in uncertain environments. Rapid internationalisation of born global companies is usually conducted in a highly uncertain environment for a novice entrepreneur.

The first studies which applied effectuation theory in international entrepreneurship research were Andersson (2011) and Harms and Schiele (2012). They state that internationalisation is basically a process of decision-making under uncertainty, therefore they claim that entrepreneurs tend to apply effectuation rather than causation. Authors agree that effectuation should be included in the future research on born globals.

\section{International networks}

Network approach suggests that traditional internationalisation models are no longer applicable to internationalised markets, where firms interact with international actors within their networks. Companies develop relationships and create strategic alliances in order to 
exploit and enhance their own resources and to gain benefits from the resources of other firms within their network (Laanti et al., 2007). Therefore, born globals have the opportunity to globalise their activities without significant human or financial resources, as networks allow them to achieve access to complementary resources in many areas like R\&D, technology, production, marketing and distribution. Sharma and Blomstermo (2003) state that the selection of foreign market entry for born global firms is based on their existing knowledge and on the knowledge supplied by their network ties. They suggest that some firms establish strong ties with internationally active firms and consequently start internationalisation processes despite substantial cultural distance to the target market.

\section{Dynamic capabilities}

Dynamic capabilities notion has evolved from the resource-based view (Barney, 1991; Nelson, 1991) and is associated with the firm's processes that use resources, for example the processes which integrate, reconfigure, relocate resources, which eventually might create market change (Eisenhardt \& Martin, 2000). Prange and Verdier (2011) propose to divide dynamic capabilities into two groups - exploitative and explorative, where exploitation refers to control, certainty, risk-reduction, while exploration corresponds to discovery, risk-taking, experimentation, flexibility and innovation. They state that both types of capabilities are applicable to internationalisation, however exploitative capabilities correspond more to the incremental internationalisation models, whereas explorative capabilities correspond to the accelerated foreign market entry. This distinction bears resemblance to the effectuation-causation model proposed by Sarasvathy (2001). Sapienza et al. (2006) argue that the earlier a firm internationalises, the more deeply embedded its dynamic capability for exploiting opportunities will be. They justify it by the fact that early exposure to internationalisation creates an imprint for adaptability to uncertain environments and a receptivity for constant change.

\section{DISCUSSION AND CONCEPTUAL FRAMEWORK DEVELOPMENT}

The above analysis leads to the development of conceptual framework on the entrepreneurial-related factors of rapid internationalisation of born global firms. In this framework the individual-level constructs are divided into two categories - those which constitute the potential of an entrepreneur before starting a born global firm (innovation and technology, entrepreneurial/ managerial knowledge, international networks), and those which reflect the logic of an entrepreneur, his decision-making schemes throughout the internationalisation process (dynamic capabilities, entrepreneurial orientation, effectuation logic).

Entrepreneurial knowledge and innovation and technology orientation are the constructs which appear in many studies on born global firms and seem to be indispensable to born global entrepreneurs. Entrepreneur's education, prior work experience, international living experience reduce the psychic distance between local and international markets (Madsen \& Servais, 1997; Oviatt \& McDougall, 1997). It allows entrepreneurs to see the whole world as a market place and gives them a global vision. Innovation and technology orientation is a construct often associated with born global entrepreneurs (Rennie, 1993; Knight \& Cavusgil, 2004), as it allows them to operate in highly internationalised markets (IT, high-technology industries) or with more traditional industries as it enables 
them to take advantage of digital sales and distribution opportunities, modern communication tools or the latest technological advances. Using their prior knowledge and technological orientation, born global entrepreneurs use their personal international networks for entering foreign markets without substantial human or financial resources.

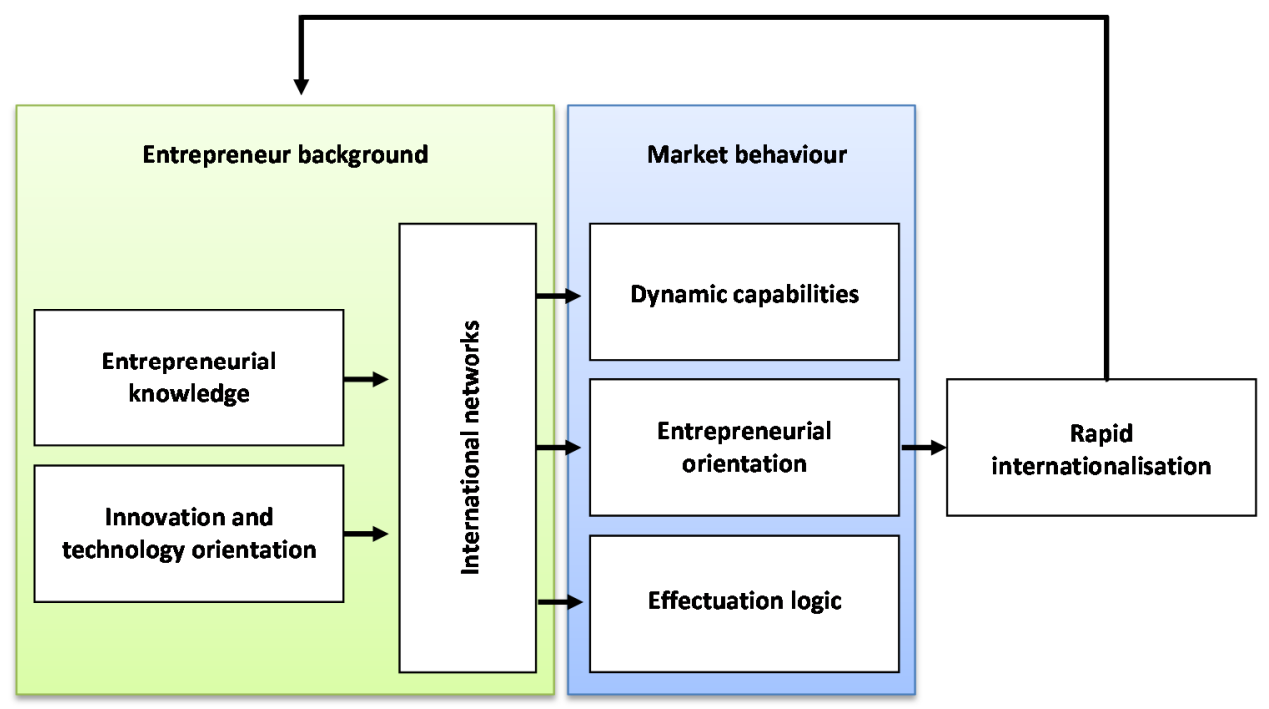

Figure 1. Entrepreneur-related factors affecting rapid internationalisation Source: own study.

The second group of constructs is related to the way of thinking of an entrepreneur, his or her behaviour and decision making models. The constructs most often mentioned in the literature are dynamic capabilities, entrepreneurial orientation and effectuation logic. It seems that there is an overlap between these concepts in the literature on international entrepreneurship. Indeed, there are common features to those constructs. All three take into consideration proactiveness of an entrepreneur and constant searching for new opportunities. However, each of them has a different meaning - dynamic capabilities notion is grounded in the resource-based view, entrepreneurial orientation is a firm-level construct originating from entrepreneurship research, and effectuation logic is an entrepreneurial way of thinking and making decisions. As such these constructs describe the behaviour of a born-global firm from different perspectives.

There is an evidence that rapid internationalisation increases a speed of firm's learning and gaining new market knowledge (Oviatt \& McDougall, 1997; Chetty \& CampbellHunt, 2004). The framework shows that after rapid internationalisation born global firms gain additional entrepreneurial and technological knowledge and access to new international network chains. This process allows to search for new market opportunities and therefore creates new possibilities for born global entrepreneurs.

Emergence of born global companies cannot be explained solely by the entrepreneurrelated constructs presented in Figure 2. Apart from entrepreneur characteristics, rapid internationalisation may be explained by a combination of external and internal factors (Pawęta, 2013). External factors are usually connected with sectoral, regional or national 
export culture, specific demand characteristics or foreign trade facilitators (Zahra \& George, 2002). Internal determinants of internationalisation are connected with possessing unique products or services which have potential of gaining worldwide acceptance and human or financial resources availability (Cavusgil \& Knight, 2009). In order to explain the rapid internationalisation phenomenon, the conceptual framework presented should be extended and include the above mentioned external and firm-level factors.

\section{CONCLUSIONS}

Multiple studies focus on determinants of internationalisation of born globals, firms which enter international markets immediately after their emergence. These determinants are based on constructs that overlap one another. This makes it more difficult to correctly interpret and compare the results of different studies on international entrepreneurship.

This paper presents a literature review of earlier research on born global companies and suggests a theoretical framework of entrepreneur-related constructs which are considered as the determinants of rapid internationalisation. Structuring entrepreneur-related constructs and building a conceptual framework is necessary for future international entrepreneurship research.

The major theoretical contribution of the study is the conceptual framework of the main entrepreneur-level determinants of rapid internationalisation. The framework illustrates two groups of entrepreneur-related constructs in an internationalisation literature - those which constitute the potential of an entrepreneur before starting a born global firm, and those which reflect the logic of an entrepreneur, his decision-making schemes throughout the internationalisation process. The importance of entrepreneurial knowledge and technological orientation seem to be one of the main explanatory factors of born global companies appearance. International networking chains are a significant factor positively influencing rapid internationalisation. The second group of factors connected with behaviour of an entrepreneur and his or her decision-making styles.

There are also managerial implications which can be drawn from the framework developed. The framework demonstrates the knowledge and capabilities needed at the early stage of a born global start-up creation and further capabilities needed for running such a firm. For governmental programs supporting firms internationalisation it indicates a shift from providing direct financing towards training of founders and management and development of international networks for born global firms.

Future research might try to integrate the reviewed entrepreneur-related constructs with organisational characteristics and external characteristics which determine born globals emergence. The results of the study are exploratory and there is a need in validating the theoretical framework through an advanced quantitative study.

One obvious shortcoming of this paper has to be acknowledged, namely its scope is limited to 94 articles. The papers taken into consideration, however, cover all important issues related to the entrepreneur-related determinants of internationalisation. However, the literature on firm internationalisation and international entrepreneurship is very rich and allows for a more in-depth analysis and comparison based on a larger sample of papers. 


\section{REFERENCES}

Ali, M. Y. (2004). Impact of firm and management related factors on firm export performance. Journal of Asia Pacific Marketing, 3(2), 5-20.

Andersen, O. (1993). On the internationalisation process of firms: A critical analysis. Journal of International Business Studies, 24(2), 209-231.

Andersson, S., \& Wictor, I. (2003). Innovative internationalisation in new firms: Born globals - the Swedish case. Journal of International Entrepreneurship, 1(3), 249-276.

Andersson, S. (2004). Internationalisation in different industrial contexts. Journal of Business Venturing, 19(6), 851-875.

Andersson, S. (2011). International entrepreneurship, born globals and the theory of effectuation. Journal of Small Business and Enterprise Development, 18(3), 627 - 643.

Aspelund, A., \& Moen O. (2001). A generation perspective on small firm internationalization: From traditional exporters and flexible specialists to born globals. In C. N. Axinn, P. Matthyssens (Eds.), Reassesing the Internationalization of the Firm (pp. 197-225). (Advances in International Marketing, Volume 11) Emerald Group Publishing Limited.

Autio, E. E., \& Yli-Renko, H. H. (1998). New, technology-based firms in small open economies - An analysis based on the Finnish experience. Research Policy, 26(9), 973-987. doi: 10.1016/S00487333(97)00054-1

Autio, E., Sapienza, H. J., \& Almeida, J. G. (2000). Effects of age at entry, knowledge intensity, and imitability on international growth. Academy of Management Journal, 43(5), 909-924. doi: $10.2307 / 1556419$

Autio, E. E. (2005). Creative tension: The significance of Ben Oviatt's and Patricia McDougall's article 'Toward a theory of international new ventures'. Journal of International Business Studies, 36(1), 9-19. doi: 10.1057/palgrave.jibs.8400117

Barney, J.B. (1991). Firm resources and sustained competitive advantage. Journal of Management, 17(1), 99-120. doi: 10.1177/014920639101700108

Bartlett, C. A. C., \& Ghoshal, S. S. (1987). Managing across borders: New organizational responses. Sloan Management Review, 29(1), 43-53.

Bell, J., \& Crick, D. (2004). Small firm internationalization and business strategy. An exploratory study of 'knowledge intensive' and 'traditional' manufacturing firms in the UK. International Small Business Journal, 22(1), 23-56.

Bilkey, W.J., \& Tesar G. (1977). The export behavior of smaller Wisconsin manufacturing firms. Journal of International Business Studies, 9, 93-98. doi: 10.1057/palgrave.jibs.8490783

Bhowmick, S. (2008). Internationalisation of entrepreneurial firms: an enactment-effectuation dance. 5th AGSE International Entrepreneurship Research Exchange (pp.785-794). Melbourne.

Bonaccorsi, A. (1992). On the relationship between firm size and export intensity. Journal of International Business Studies, 23(4), 605-635. doi: 10.1057/palgrave.jibs.8490280

Brennan, L., \& Garvey, D. (2009). The role of knowledge in internationalization. Research in International Business and Finance, 23(2), 120-133. doi: 10.1016/j.ribaf.2008.03.007

Burgel, O., \& Murray, G. C. (2000). The international market entry choices of start-up companies in high-technology industries. Journal of International Marketing, 8(2), 33-62. doi: 10.1509/jimk.8.2.33.19624

Campa, J. M., \& Guillen, M. F. (1999). The internalisation of exports: Firm- and location-specific factors in a middle-income country. Management Science, 45(11), 1463-1478. 
Cavusgil, S.T. (1980). On the internationalization process of firms. European Research, 8, 273-281.

Cavusgil, S.T., \& Knight, G. (2009). Born Global Firms: A New International Enterprise. New York: Business Expert Press.

Chandra, Y., Styles, C., \& Wilkinson, I. (2009). The recognition of first time international entrepreneurial opportunities. International Marketing Review, 26(1), 30-61. doi: 10.1108/02651330910933195

Chetty, S., \& Campbell-Hunt C. (2004). A strategic approach to internationalisation: A traditional versus “Born Global" approach. Journal of International Marketing, 12(1), 57-81.

Coviello, N., \& Munro, H. (1997). Network relationships and the internationalisation process of small software firms. International Business Review, 6(4), 361-386. doi: 10.1016/S09695931(97)00010-3

Covin, J.G., \& Slevin, D.P. (1989). Strategic management of small firms in hostile and benign environments. Strategic Management Journal, 10(1), 75-89. doi: 10.1002/smj.4250100107

Crick, D., \& Jones, M.V. (2000). Small high-technology firms and international high-technology markets. Journal of International Marketing, 8(2), 63-85. doi: 10.1509/jimk.8.2.63.19623

Crick, D., \& Crick, J. (2014). The internationalization strategies of rapidly internationalizing high-tech UK SMEs. European Business Review, 26(5), 421- 448.

Eisenhardt, K. M. K., \& Martin, J. A. J. (2000), Dynamic Capabilities: What are they? Strategic Management Journal, 21(10/11), 1105-1121. doi: 10.1002/1097-0266(200010/11)21:10/11\% 3C1105::AID-SMJ133\%3E3.0.CO;2-E

Erikksson, K., Johanson, J., \& Majkard, A. (2000). Effect of variation on knowledge accumulation in the internationalization process. International Studies on Management and Organisation, 30(1), 26-44.

Fan, T., \& Phan, P. (2007). International new ventures: Revisiting the influences behind the 'bornglobal' firm. Journal of International Business Studies, 38(7), 1113-1131. doi: 10.1057/palgrave.jibs. 8400308

Fernhaber, S. A., McDougall, P. P., \& Oviatt, B. M. (2007). Exploring the role of industry structure in new venture internationalization. Entrepreneurship: Theory \& Practice, 31(4), 517-542. doi: 10.1111/j.1540-6520.2007.00186.x

Fillis, I. (2001). Small firm internationalization: an investigative survey and future research directions. Management Decision, 39(9), 767-783.

Francis, J., \& Collins-Dodd, C. (2000). The impact of firms' expert orientation on the export performance of high-tech small and medium-sized enterprises. Journal of International Marketing, 8(3), 84-103.

Freeman, S., Edwards, R., \& Schroder, B. (2006). How smaller born-global firms use networks and alliances to overcome constraints to rapid internationalization. Journal of International Marketing, 14(3), 33-63. doi: 10.1509/jimk.14.3.33

Freeman, S., \& Cavusgil, S. T. (2007). Toward a typology of commitment states among managers of born-global firms: A study of accelerated internationalization. Journal of International Marketing, 15(4), 1-40.

Gabrielsson, M. M., \& Gabrielsson, P. P. (2003). Global marketing strategies of born globals and globalising internationals in the ICT field. Journal of Euro-Marketing, 12(3/4), 123-145. doi: 10.1300/J037v12n03_08

Gabrielson, M., \& Kirpalani, V.H.M. (2004). Born globals: How to reach new business space rapidly. International Business Review, 13(5), 555-571. doi: 10.1016/j.ibusrev.2004.03.005 
Gabrielsson, M., Kirpalani, V.H.M., Dimitratos, P., Solberg, C.A., \& Zucchella A. (2008). Born globals: Propositions to help advance the theory. International Business Review, 17(4), 385-401. doi: 10.1016/j.ibusrev.2008.02.015

Gabrielsson, P., Gabrielsson M., \& Seppälä, T. (2012). Marketing strategies for foreign expansion of companies originating in small and open economies: The consequences of strategic fit and performance. Journal of International Marketing, 20(2), 25-48. doi: 10.1509/jim.11.0068

Galkina, T., \& Chetty, S. (2015). Effectuation and networking of internationalizing SMEs. Management International Review, 55(5), 647-676. doi: 10.1007/s11575-015-0251-x

Gassmann, O., \& Keupp, M. M. (2007). The competitive advantage of early and rapidly internationalising SMEs in the biotechnology industry: A knowledge-based view. Journal of World Business, 42, 350-366. doi: 10.1016/j.jwb.2007.04.006

Harms, R., \& Schiele, H. (2012). Antecedents and consequences of effectuation and causation in the international new venture creation process. Journal of International Entrepreneurship, 10, 95116. doi: $10.1007 / \mathrm{s} 10843-012-0089-2$

Hashai, N., \& Almor, T. (2004). Gradually internationalising 'Born Global' firms: An oxymoron? International Business Review, 13(4), 465-483.

Jantunen, A., Puumalainen, K., Saarenketo, S., \& Kyläheiko, K. (2005). Entrepreneurial orientation, dynamic capabilities and international performance. Journal of International Entrepreneurship, 3, 223-243. doi: 10.1007/s10843-005-11332

Johanson J., \& Vahlne J.E. (1977). The internationalisation process of the firm. Journal of International Business Studies, 8, 23-32.

Johanson J., \& VahIne J.E. (1990). The Mechanisms of Internationalisation. International Marketing Review, 7(4), 11-24. doi: 10.1108/02651339010137414

Johanson, J., \& Wiedersheim-Paul, F. (1975). The internationalization process of the firm - Four Swedish cases. Journal of Management Studies, 12(3), 305-322.

Johanson, J.E. (2004). Factors influencing the early internationalization of high technology start-ups: US and UK evidence. Journal of International Entrepreneurship, 2, 139-154.

Jones, M. V. (1999). The internationalization of small high-technology firms. Journal of International Marketing, 7(4), 15-41.

Jones, M. V. M., \& Coviello, N. E. N. (2005). Internationalisation: Conceptualising an entrepreneurial process of behaviour in time. Journal of International Business Studies, 36(3), 284-303. doi: 10.1057/palgrave.jibs. 8400138

Keeble, D., Lawson, C., Lawton-Smith, H., Moore, B., \& Wilkinson, F. (1998). Internationalisation processes, networking and local embeddedness in technology-intensive small firms. Small Business Economics, 11(4), 327-342.

King, A. A., \& Tucci, C. L. (2002). Incumbent entry into new market niches: The role of experience and managerial choice in the creation of dynamic capabilities. Management Science, 48, 171186. doi: $10.1287 / \mathrm{mnsc} .48 .2 .171 .253$

Knight, G.A., \& Cavusgil, S.T. (1996). The born global firm: A challenge to traditional internationalization theory. In S. T. Cavusgil \& T. Madsen (Eds.), Advances in International Marketing (pp.1126), CT, Greenwich: JAI Press.

Knight, G.A. (2000). Entrepreneurship and marketing strategy: The SME under globalization. Journal of International Marketing, 8(2), 12-32. doi: 10.1509/jimk.8.2.12.19620

Knight, G.A. (2001). Entrepreneurship and strategy in the international SME. Journal of International Management, 7, 155-171. doi: 10.1016/S1075-4253(01)00042-4 
Knight, G. A., \& Cavusgil, S. T. (2004). Innovation, organizational capabilities and the born-global firm. Journal of International Business Studies, 35(2), 124-141. doi: 10.1057/palgrave.jibs.8400071

Knight, G. A., Madsen, T. T., \& Servais, P. P. (2004). An inquiry into born-global firms in Europe and the USA. International Marketing Review, 21(6), 645-665. doi: 10.1108/02651330410568060

Knight, G.A., \& Liesh P.W. (2016). Internationalization: From incremental to born global. Journal of World Business, 51(1), 93-102. doi: 10.1016/j.jwb.2015.08.011

Kuivalainen, O., Sundqvist S., \& Servais P. (2007). Firms' degree of born-globalness, international entrepreneurial orientation and export performance. Journal of World Business, 42, 253-267.

Kuivalainen, O., Saarenkato, S., \& Puumalainen, K. (2012). Start-up patterns of internationalization: A framework and its application in the context of knowledge-intensive SMEs. European Management Journal, 30(4), 372-385. doi: 10.1016/j.emj.2012.01.001

Kundu, S.K., \& Katz, J.A. (2003). Born-international SMEs: Bi-level impacts of resources and intentions. Small Business Economics, 20, 25-47.

Laanti, R., Gabrielsson, M., \& Gabrielsson, P. (2007). The globalisation strategies of business-to-business born global firms in the wireless technology industry. Industrial Marketing Management, 36(8), 1104-1117.

Larimo, J. (2006). Different types of exporting SME's: Similarities and differences in export performance. Advances in International Marketing, 17, 17-62.

Laurell, H., Anderson, S., \& Achtenhagen, L. (2013). The importance of industry context for new venture internationalisation: A case study from the life sciences. Journal of International Entrepreneurship, 11, 297-319. doi: 10.1007/s10843-013-0116-y

Loane, S., McNaughton, R. B., \& Bell, J. (2004). The internationalization of internet-enabled entrepreneurial firms: Evidence from Europe and North America. Canadian Journal of Administrative Sciences, 21(1), 79-96. doi: 10.1111/j.1936-4490.2004.tb00324.x

Loane, S., Bell, J. D., \& McNaughton, R. (2007). A cross-national study on the impact of management teams on the rapid internationalisation of small firms. Journal of World Business, 42(4), 489504.

Lopez, L.E., Kundu, S.K., \& Ciravenga, L. (2009). Born global or born regional? Evidence from an exploratory study in the Costa Rican software industry. Journal of International Business Studies, 40, 1228-1238. doi: 10.1057/jibs.2008.69

Lu, J., \& Beamish, P. (2001). The internationalization and performance of SMEs. Strategic Management Journal, 22, 565-586. doi: 10.1002/smj.184.abs

Lumpkin, G. T., \& Dess, G. G. (1996). Clarifying the entrepreneurial orientation construct and linking it to performance. Academy of Management Review, 21, 135-172. doi: 10.5465/AMR.1996.9602161568

Madsen, T.K., \& Servais, P. (1997). The internationalization of born global firms - an evolutionary process. International Business Review, 6(6), 561-583.

Mainela, T., \& Puhakka, V. (2008). Organising new business in a turbulent context: Opportunity discovery and effectuation for IJV development in transition markets. Journal of International Entrepreneurship, 7, 111-134. doi: 10.1007/s10843-008-0034-6

McAuley, A. (1999). Entrepreneurial instant exporters in the Scottish arts and crafts sector. Journal of International Marketing, 7(4), 67-82.

McDougall, P.P. (1989). International versus domestic entrepreneurship: New venture strategic behavior and industry structure. Journal of Business Venturing, 4(6), 387-400. doi: 10.1016/08839026(89)90009-8 
McDougall, P. P., Shane, S., \& Oviatt, B.M. (1994). Explaining the formation of international new ventures: The limits of theories from international business research. Journal of Business Venturing, 9(6), 469-487.

McDougall, P.P., \& Oviatt, B.M. (2000). International entrepreneurship: The intersection of two research paths. Academy of Management Journal, 43(5), 902-906. doi: 10.2307/1556418

McDougall, P.P., \& Oviatt, B. M. (2003). Some fundamental issues in international entrepreneurship. Entrepreneurship Theory \& Practice. Retrieved on December 10, 2015 from http://citeseerx.ist.psu.edu/viewdoc/download?doi=10.1.1.210.861\&rep=rep1\&type=pdf

Moen, O., Gavlen, N., \& Endersen, I. (2004). Internationalization of small, computer software firms. Entry forms and market selection. European Journal of Marketing, 38(9/10), 1236 - 1251.

Moen, O., \& Servais, P. (2002). Born global or gradual global? Examining the export behaviour of small and medium-sized enterprises. Journal of International Marketing, 10(3), 49-72.

Nelson, R.R. (1991). Why do firms differ, and how does it matter? Strategic Management Journal, Winter Special Issue 12, 61-74. doi: 10.1002/smj.4250121006

Oviatt, B.M., \& McDougall, P.P. (1994). Toward a theory of international new ventures. Journal of International Business Studies, 25(1), 45-65. doi: 10.1057/palgrave.jibs.8490193

Pawęta, E. (2013). The determinants of born global companies emergence in Central European countries. Entrepreneurial Business and Economics Review, 1(2), 41-50. doi: http://dx.doi.org/10.15678/EBER.2013.010204

Pellegrino, J.M., \& McNaughton, R.B. (2015). The co-evolution of learning and internationalization strategy in international new ventures. Management International Review, 55(11), 457-483. doi: 10.1007/s11575-015-0246-7

Prange, C., \& Verdier, S. (2011). Dynamic capabilities, internationalization processes and performance. Journal of World Business, 46(1), 126-133. doi: 10.1016/j.jwb.2010.05.024

Prashantham, S., \& Berry, M.M.J. (2004). The small knowledge-intensive firm: a conceptual discussion of its characteristics and internationalisation. International Journal of Entrepreneurship and Innovation Management, 4, 150-155. doi: 10.1504/IJEIM.2004.004722

Preece, S.B., Miles, G., \& Baetz, M. (1999). Explaining the international intensity and global diversity of early-stage technology-based firms. Journal of Business Venturing, 14, 259-281. doi: 10.1016/S0883-9026(97)00105-5

Rennie, M.W. (1993). Global competitiveness: Born Global. The McKinsey Quarterly, 4, 45-52.

Rialp, A. A., Rialp, J. J., \& Knight, G. A. G. (2005). The phenomenon of early internationalizing firms: What do we know after a decade (1993-2003) of scientific inquiry? International Business Review, 14(2), 147-166. doi: 10.1016/j.ibusrev.2004.04.006

Roudini, A., \& Osman M. (2012). The role of international entrepreneurship capability on international performance in born global firms. iBusiness, 4(2), 126-135. doi: 10.4236/ib.2012.42015

Rutihinda, C. (2008). Factors influencing the internationalization of small and medium size enterprises. International Business \& Economics Research Journal, 7(12).

Sapienza, H. J., Autio, E., George, G., \& Zahra, S. A. (2006). A capability perspective on the effects of early internationalization on firm survival and growth. Academy of Management Review, 31, 914-933. doi: 10.5465/AMR.2006.22527465

Sarasvathy, S. D. (2001). Causation and effectuation: Towards a theoretical shift from economic ineveitability to entrepreneurial contingency. Academy of Management Review, 26(2), 243-288. doi: 10.5465/AMR.2001.4378020 
Sarasvathy, S., Kumar, K., York, J.G., \& Bhagavatula, S. (2014). An effectual approach to international entrepreneurship: Overlaps, challenges, and provocative possibilities. Entrepreneurship, Theory and Practice, 38(11), 71-93. doi: 10.1111/etap.12088

Schlegelmilch, B. B., \& Crook, J. N. (1988). Firm-level determinants of export intensity. Managerial and Decision Economics, 9(4), 291-300. doi: 10.1002/mde.4090090408

Schweizer, R., Vahlne, J.-E., \& Johanson, J. (2010). Internationalization as an entrepreneurial process. Journal of International Entrepreneurship, 8, 343-370. doi: 10.1007/s10843-010-0064-8

Sharma, D.D., \& Blomstermo, A. (2003). The internationalization process of Born Globals: a network view. International Business Review, 12(6), 739-753. doi: 10.1016/j.ibusrev.2003.05.002

Shrader, R. C., Oviatt, B. M., \& McDougall, P. P. (2000). How new ventures exploit trade-offs among international risk factors: Lessons for the accelerated internationalisation of the $21^{\text {st }}$ century. Academy of Management Journal, 43(6), 1227-1247. doi: 10.2307/1556347

Vernon, R. (1966). International investment and international trade in the product life cycle. The Quarterly Journal of Economics, 80(2), 190-207.

Weerawardena, J., Sullivan Mort, G., Liesch, P. W., \& Knight, G. (2007). Conceptualizing accelerated internationalization in the born global firm: A dynamic capabilities perspective. Journal of World Business, 42, 294-306. doi: 10.1016/j.jwb.2007.04.004

Wickramasekera, R., \& Bamberry, G. (2003). Exploration of born globals/International new ventures: Some evidence from the Australian wine industry. Australasian Journal of Regional Studies, 9(2), 207-220.

Wolff, J. A., \& Pett, T. L. (2000). Internationalization of small firms: An examination of export competitive patterns, firm size, and export performance. Journal of Small Business Management, 38(2), 34-47.

Wright, M., Westhead, P., \& Ucbasaran, D. (2007). Internationalisation of small and medium-sized enterprises (SMEs) and international entrepreneurship: A critique and policy implications. Regional Studies, 41(7), 1013-1030.

Zahra, S. A., \& George, G. (2002). Absorptive capacity: A review, reconcepualisation, and extension. Academy of Management Review, 27(2), 185-203.

Zahra, S. A., Ireland, R. D., \& Hitt, M. A. (2000). International expansion by new venture firms: International diversity, mode of market entry, technological learning, and performance. Academy of Management Journal, 43 (5), 925-950. doi: 10.2307/1556420

Zhang, M., Tansuhaj, P., \& McCullough, J. (2009). International entrepreneurial capability: The measurement and a comparison between born global firms and traditional exporters in China. Journal of International Entrepreneurship, 7, 292-322. doi: 10.1007/s10843-009-0042-1

Zucchella, A., Palamara, G., \& Denicolai, S. (2007). The drivers of the early internationalization of the firm. Journal of World Business, 42, 268-280. doi: 10.1016/j.jwb.2007.04.008 


\section{Author}

\section{Elena Pawęta}

Master in Human Resources Management (Saint Petersburg State University, Russia); Master in Business and Organisation (Technical University of Lodz, Poland); PhD student in the Faculty of Economics and Sociology at the University of Lodz, Poland. Her main research interests are entrepreneurship and business planning. She is particularly interested in rapid internationalisation of enterprises.

\section{Correspondence to:}

Elena Pawęta

University of Lodz

Faculty of Economics and Sociology

UI. POW 3/5, 90-255, Łódź, Poland

elena.paweta@gmail.com

\section{Acknowledgements and Financial Disclosure}

The author would like to thank the anonymous referees for their useful comments, which allowed to increase the value of this article.

The author would like to express gratitude to prof. Agnieszka Kurczewska for her valuable comments of the draft version of this paper and her inspiration to further research study.

\section{Copyright and License}

This article is published under the terms of the Creative Commons Attribution - NonCommercial - NoDerivs (CC BY-NC-ND 3.0) License http://creativecommons.org/licenses/by-nc-nd/3.0/ 


\begin{tabular}{|c|c|c|c|c|}
\hline Year & Author, Year & Sample & $\begin{array}{l}\text { Research } \\
\text { method }\end{array}$ & Main results \\
\hline 1966 & Vernon, 1966 & & $\begin{array}{l}\text { Conceptual } \\
\text { paper }\end{array}$ & $\begin{array}{l}\text { Internationalisation process follows the product life cycle. The main stages are new product stage, } \\
\text { maturing product stage and standardized product stage. }\end{array}$ \\
\hline 1977 & $\begin{array}{l}\text { Johanson \& } \\
\text { Vahlne, } 1977\end{array}$ & & $\begin{array}{l}\text { Conceptual } \\
\text { paper }\end{array}$ & $\begin{array}{l}\text { The model of internationalisation process is developed based on the gradual acquisition and use of } \\
\text { knowledge about foreign markets. }\end{array}$ \\
\hline 1977 & $\begin{array}{l}\text { Bilkey \& Tesar, } \\
1977\end{array}$ & 423 SMEs, USA & Quantitative & $\begin{array}{l}\text { Stage internationalisation model is presented. Different factors influence firms on different stages of } \\
\text { internationalisation process. }\end{array}$ \\
\hline 1980 & Cavusgil, 1980 & & $\begin{array}{l}\text { Conceptual } \\
\text { paper }\end{array}$ & $\begin{array}{l}\text { An innovation-related internationalisation model is presented. The main stages are: domestic } \\
\text { marketing, pre-export stage, experimental involvement, active involvement and finally committed } \\
\text { involvement. }\end{array}$ \\
\hline 1987 & $\begin{array}{l}\text { Bartlett \& } \\
\text { Ghoshal, } 1987\end{array}$ & & $\begin{array}{l}\text { Conceptual } \\
\text { paper }\end{array}$ & $\begin{array}{l}\text { Company's ability to develop transnational organizational capability and management mentality is the } \\
\text { key factor of international success. }\end{array}$ \\
\hline 1988 & $\begin{array}{l}\text { Schlegelmilch \& } \\
\text { Crook, } 1988\end{array}$ & $\begin{array}{l}105 \text { exporters from } \\
\text { mechanical engineering } \\
\text { industry, UK }\end{array}$ & Quantitative & $\begin{array}{l}\text { Export intensity is positively related to the number of senior managers who speak a foreign language } \\
\text { and to R\&D intensity. }\end{array}$ \\
\hline 1989 & $\begin{array}{l}\text { Covin \& Slevin, } \\
1989\end{array}$ & $\begin{array}{l}161 \text { small } \\
\text { manufacturers, USA }\end{array}$ & Quantitative & $\begin{array}{l}\text { Small businesses can survive in hostile environments because of their organic structure, } \\
\text { entrepreneurial strategic posture and awareness of industry trends. }\end{array}$ \\
\hline 1990 & $\begin{array}{l}\text { Johanson \& } \\
\text { Vahlne, } 1990\end{array}$ & & $\begin{array}{l}\text { Conceptual } \\
\text { paper }\end{array}$ & $\begin{array}{l}\text { Internationalisation process is influenced by strategic thinking, strategic action, emergent } \\
\text { developments, chance and necessity. }\end{array}$ \\
\hline 1992 & Bonaccorsi, 1992 & $\begin{array}{l}\text { Survey among } \\
\text { manufacturers, Italy }\end{array}$ & Quantitative & The theory that size of a company is positively related to export intensity is being challenged. \\
\hline 1992 & Andersen, 1992 & & $\begin{array}{l}\text { Conceptual } \\
\text { paper }\end{array}$ & $\begin{array}{l}\text { Uppsala internationalisation model and innovation-related models are analysed, compared and } \\
\text { modified. }\end{array}$ \\
\hline 1993 & Rennie, 1993 & $\begin{array}{l}\text { Manufacturers from } \\
\text { Australia }\end{array}$ & $\begin{array}{l}\text { Qualitative, } \\
\text { Quantitative }\end{array}$ & $\begin{array}{l}\text { Born globals create value through innovative technology and product design. Technology is a critical } \\
\text { competitive lever. They compete in niche markets, are very flexible and move fast. }\end{array}$ \\
\hline
\end{tabular}




\begin{tabular}{|c|c|c|c|c|}
\hline 1994 & $\begin{array}{l}\text { Oviatt \& } \\
\text { McDougall, } 1994\end{array}$ & & $\begin{array}{l}\text { Conceptual } \\
\text { paper }\end{array}$ & $\begin{array}{l}\text { Three potential sources of internationalisation are proposed - international resource base } \\
\text { asymmetries, knowledge regeneration advantages and dynamic capability effect. }\end{array}$ \\
\hline 1997 & $\begin{array}{l}\text { Coviello \& } \\
\text { Munro, } 1997\end{array}$ & $\begin{array}{l}4 \text { software developers, } \\
\text { New Zealand }\end{array}$ & Qualitative & $\begin{array}{l}\text { Internationalisation of small software firms is driven by a set of formal and informal network } \\
\text { relationships. }\end{array}$ \\
\hline 1997 & $\begin{array}{l}\text { Madsen \& } \\
\text { Servais, } 1997\end{array}$ & $\begin{array}{l}9 \text { case studies, different } \\
\text { countries }\end{array}$ & Qualitative & $\begin{array}{l}\text { Several propositions on born global firms characteristics are presented. Among the individual-level } \\
\text { characteristics of born globals are: international experience of an entrepreneur, his or her innovative } \\
\text { skills, networks with partners and relying on their supplementary competences. Other characteristics } \\
\text { are: niche orientation, level of internationalisation of the industry, small domestic markets. }\end{array}$ \\
\hline 1998 & $\begin{array}{l}\text { Autio \& Yli- } \\
\text { Renko, } 1998\end{array}$ & $\begin{array}{l}\text { Panel survey of the } \\
\text { Finnish national system } \\
\text { of innovation and } \\
\text { technology }\end{array}$ & Quantitative & $\begin{array}{l}\text { New technology-based firms in small open economies grow as organic parts of technology supply } \\
\text { networks maintained by large firms. }\end{array}$ \\
\hline 1998 & $\begin{array}{l}\text { Keeble et al., } \\
1998\end{array}$ & $\begin{array}{l}100 \text { technology-intensive } \\
\text { SMEs, Great Britain }\end{array}$ & Quantitative & $\begin{array}{l}\text { Technology-based smaller firms are engaged in a range of international networks. Those firms which } \\
\text { report high levels of internationalisation differ from those more nationally-oriented in terms of size, } \\
\text { age, research intensity, university links and innovativeness. }\end{array}$ \\
\hline 1998 & $\begin{array}{l}\text { Preece et al., } \\
1998\end{array}$ & $\begin{array}{l}75 \text { surveys of small } \\
\text { technology-based firms, } \\
\text { Canada }\end{array}$ & Quantitative & $\begin{array}{l}\text { Authors try to explain intensity of foreign sales as well as global diversity of the markets in which they } \\
\text { operate. Attitudes towards foreign markets helped to explain international intensity, however firm age } \\
\text { was positively associated with global diversity. }\end{array}$ \\
\hline 1999 & $\begin{array}{l}\text { Campa \& Guillen, } \\
1999\end{array}$ & $\begin{array}{l}837 \text { manufacturing } \\
\text { companies, Spain }\end{array}$ & Quantitative & $\begin{array}{l}\text { Greater level of intangible technological assets, product variability and resource availability increase } \\
\text { the likelihood of internationalisation. }\end{array}$ \\
\hline 1999 & Jones, 1999 & $\begin{array}{l}196 \text { small high- } \\
\text { technology firms, UK }\end{array}$ & Quantitative & $\begin{array}{l}\text { Early internationalisation of small firms should be viewed as a holistic process, where interrelated } \\
\text { decisions and processes combine to accomplish a firm's individual pattern of internationalisation. }\end{array}$ \\
\hline 1999 & McAuley, 1999 & $\begin{array}{l}3 \text { case studies from arts } \\
\text { and crafts business, } \\
\text { Scotland }\end{array}$ & Qualitative & $\begin{array}{l}\text { The key influences on instant internationalisation are classified as product related (design, quality, } \\
\text { price, delivery), personal and psychological (attitude, family, personality, education), industry related } \\
\text { (sectoral influence, global market)and cognitive (networks, access to know-how, business skills). }\end{array}$ \\
\hline 2000 & $\begin{array}{l}\text { Burgel \& Murray, } \\
2000\end{array}$ & $\begin{array}{l}246 \text { technology-based } \\
\text { start-ups with } \\
\text { international activities, } \\
\text { UK }\end{array}$ & Quantitative & $\begin{array}{l}\text { Issues of technological innovativeness and historic channel experience of the firm are particularly } \\
\text { strong determinants of entry mode choice. }\end{array}$ \\
\hline 2000 & $\begin{array}{l}\text { Eisenhardt \& } \\
\text { Martin, } 2000\end{array}$ & & $\begin{array}{l}\text { Conceptual } \\
\text { paper }\end{array}$ & $\begin{array}{l}\text { Dynamic capabilities allow for emergent adaptation to new situations. When new knowledge must be } \\
\text { rapidly gained, experimental activities such as prototyping, real-time information and experimenting } \\
\text { replace strategic analysis. }\end{array}$ \\
\hline
\end{tabular}




\begin{tabular}{|c|c|c|c|c|}
\hline 2000 & Knight, 2000 & $\begin{array}{l}268 \text { manufacturing SMEs } \\
\text { operating in highly } \\
\text { globalized industries, } \\
\text { USA }\end{array}$ & $\begin{array}{l}\text { Qualitative, } \\
\text { Quantitative }\end{array}$ & $\begin{array}{l}\text { Entrepreneurial orientation is a key variable for SMEs involved in international activities and has a } \\
\text { positive impact on marketing strategy. }\end{array}$ \\
\hline 2000 & \begin{tabular}{|l|} 
Francis \& Collins- \\
Dodd, 2000
\end{tabular} & $\begin{array}{l}88 \text { small and medium- } \\
\text { sized high-tech } \\
\text { exporters, Canada }\end{array}$ & Quantitative & $\begin{array}{l}\text { Proactive export orientation is determining international success in the uncertain high-tech } \\
\text { environment. }\end{array}$ \\
\hline 2000 & $\begin{array}{l}\text { McDougall \& } \\
\text { Oviatt, } 2000\end{array}$ & & $\begin{array}{l}\text { Conceptual } \\
\text { paper }\end{array}$ & $\begin{array}{l}\text { The article integrates the two areas of research - business internationalisation and entrepreneurship - } \\
\text { It initiates the new branch of research, i.e. international entrepreneurship. }\end{array}$ \\
\hline 2000 & $\begin{array}{l}\text { Wolff \& Pett, } \\
2000\end{array}$ & $\begin{array}{l}157 \text { active exporters, } \\
\text { USA }\end{array}$ & Quantitative & $\begin{array}{l}\text { Size of the firm does not influence its competitive patterns and export intensity. Stage } \\
\text { internationalisation models are no longer the only representation of how small firms pursue an } \\
\text { international strategy. }\end{array}$ \\
\hline 2000 & Zahra et al., 2000 & 103 mail surveys, USA & Quantitative & $\begin{array}{l}\text { Organizational learning, exposure to new knowledge and technological learning influence early } \\
\text { internationalisation of firms. There is a positive association between the use of acquisitions and the } \\
\text { breadth of technological learning. }\end{array}$ \\
\hline 2000 & $\begin{array}{l}\text { Crick \& Jones, } \\
2000\end{array}$ & $\begin{array}{l}88 \text { case studies of } \\
\text { technologically oriented } \\
\text { SMEs, UK }\end{array}$ & Qualitative & $\begin{array}{l}\text { Entrepreneurial issues have important influence on the nature and pace of internationalisation in high- } \\
\text { tech industry. Among them - experience in international markets, network of customers and contacts, } \\
\text { decision to engage in international markets immediately after founding. }\end{array}$ \\
\hline 2001 & Knight, 2001 & $\begin{array}{l}268 \text { manufacturing } \\
\text { SMEs, USA }\end{array}$ & $\begin{array}{l}\text { Qualitative, } \\
\text { Quantitative }\end{array}$ & $\begin{array}{l}\text { International entrepreneurial orientation is enhanced by preparation for internationalisation, } \\
\text { technology acquisition, marketing strategy. }\end{array}$ \\
\hline 2001 & Fillis, 2001 & & $\begin{array}{l}\text { Literature } \\
\text { review }\end{array}$ & $\begin{array}{l}\text { Such entrepreneurial competences as a global vision, a focused approach to doing business and the } \\
\text { ability to recognize opportunities are drivers of born global's competitive advantage. }\end{array}$ \\
\hline
\end{tabular}




\begin{tabular}{|c|c|c|c|c|}
\hline 2001 & $\begin{array}{l}\text { Lu \& Beamish, } \\
2001\end{array}$ & 164 Japanese SMEs & Quantitative & $\begin{array}{l}\text { When firm first begins FDI activity, profitability declines, however using alliances with partners with } \\
\text { local knowledge can be an effective strategy on foreign markets. }\end{array}$ \\
\hline 2001 & $\begin{array}{l}\text { Aspelund \& } \\
\text { Moen, } 2001\end{array}$ & $\begin{array}{l}208 \text { exporting firms, } \\
\text { Norway }\end{array}$ & Quantitative & $\begin{array}{l}\text { Born global firms are different from traditional exporters because of their strong technological } \\
\text { competitiveness, their niche focus and the use of advanced communication technology. }\end{array}$ \\
\hline 2002 & $\begin{array}{l}\text { Moen \& Servais, } \\
2002\end{array}$ & $\begin{array}{l}677 \text { small and medium- } \\
\text { sized exporting firms, } \\
\text { Norway, Denmark, } \\
\text { France }\end{array}$ & Quantitative & $\begin{array}{l}\text { Global orientation, export intensity and market selection are not influenced by the firm's year of } \\
\text { establishment. Future export involvement depends on the firm's behaviour shortly after its } \\
\text { establishment. }\end{array}$ \\
\hline 2002 & $\begin{array}{l}\text { King \& Tucci, } \\
2002\end{array}$ & $\begin{array}{l}174 \text { firms from disk-drive } \\
\text { industry, USA }\end{array}$ & Quantitative & $\begin{array}{l}\text { Experience in previous markets increases the probability that a firm would enter a new market. } \\
\text { Managers choose to enter new markets to increase their international experience. }\end{array}$ \\
\hline 2003 & $\begin{array}{l}\text { Andersson \& } \\
\text { Wictor, } 2003\end{array}$ & $\begin{array}{l}4 \text { case studies of born } \\
\text { global firms, Sweden }\end{array}$ & Qualitative & $\begin{array}{l}\text { Active entrepreneurs who recognize global opportunities are crucial for implementation of born global } \\
\text { strategies within their networks. }\end{array}$ \\
\hline 2003 & $\begin{array}{l}\text { Gabrielsson \& } \\
\text { Gabrielsson, } \\
2003\end{array}$ & & $\begin{array}{l}\text { Conceptual } \\
\text { paper }\end{array}$ & $\begin{array}{l}\text { Two globalisation paths are distinguished - born globals and globalising internationals. The importance } \\
\text { of co-operation in vertical and horizontal value networks is discussed. }\end{array}$ \\
\hline 2003 & $\begin{array}{l}\text { Kundu \& Katz, } \\
2003\end{array}$ & $\begin{array}{l}47 \text { born-international } \\
\text { firms from Indian } \\
\text { software industry, India }\end{array}$ & $\begin{array}{l}\text { Qualitative, } \\
\text { Quantitative }\end{array}$ & $\begin{array}{l}\text { During the early stages of firm development owner characteristics (not firm or industry) play pivotal } \\
\text { role in the performance of the company. }\end{array}$ \\
\hline 2003 & $\begin{array}{l}\text { Wickramasekera } \\
\text { \& Bamberry, } \\
2003\end{array}$ & $\begin{array}{l}106 \text { surveys within the } \\
\text { wine industry, Australia }\end{array}$ & Quantitative & $\begin{array}{l}\text { Born global firms are only high technology firms, but also regional firms such as wineries. One of the } \\
\text { reasons for being born global are prior managerial experience in exporting. }\end{array}$ \\
\hline 2003 & $\begin{array}{l}\text { Sharma \& } \\
\text { Blomstermo, } \\
2003\end{array}$ & 2 case studies, Sweden & Qualitative & $\begin{array}{l}\text { Internationalisation process of born global firms is based on learning through networks. They usually } \\
\text { possess international market knowledge before their first market entry. }\end{array}$ \\
\hline 2003 & $\begin{array}{l}\text { McDougall \& } \\
\text { Oviatt, } 2003\end{array}$ & & $\begin{array}{l}\text { Conceptual } \\
\text { paper }\end{array}$ & $\begin{array}{l}\text { The main concepts which are being discussed are network theory and learning and knowledge } \\
\text { management. }\end{array}$ \\
\hline 2004 & Ali, 2004 & $\begin{array}{l}60 \text { exporting companies, } \\
\text { Australia }\end{array}$ & Quantitative & $\begin{array}{l}\text { Firm-related factors (firm size, separate export department) are not significant for export performance, } \\
\text { however management-related factors have significant impact on export volume and export intensity. }\end{array}$ \\
\hline
\end{tabular}




\begin{tabular}{|c|c|c|c|c|}
\hline 2004 & Andersson, 2004 & $\begin{array}{l}\text { Cases from mature } \\
\text { industry and high-growth } \\
\text { industry, Sweden }\end{array}$ & Qualitative & $\begin{array}{l}\text { Firms in different industries have different international patterns. In the early phase of firm's } \\
\text { development personal networks are important, however in the later stages firm's actions are of a } \\
\text { greater significance to the industry as a whole. }\end{array}$ \\
\hline 2004 & Bell \& Crick, 2004 & $\begin{array}{l}30 \text { SMEs, including } 15 \\
\text { from knowledge- } \\
\text { intensive sectors and } 15 \\
\text { from traditional sectors, } \\
\text { UK }\end{array}$ & Qualitative & $\begin{array}{l}\text { Product and process innovations stimulate international growth of a company. There is a significant } \\
\text { difference in the way of internationalisation in knowledge-intensive sectors and in the traditional } \\
\text { sectors, what confirms influence of the external environment, especially in the early stages of } \\
\text { international development. }\end{array}$ \\
\hline 2004 & $\begin{array}{l}\text { Chetty \& } \\
\text { Campbell-Hunt, } \\
2004\end{array}$ & $\begin{array}{l}16 \text { case studies, New } \\
\text { Zealand }\end{array}$ & Qualitative & $\begin{array}{l}\text { Born globals start as traditional firms but are radically transformed in the process of achieving global } \\
\text { reach. They require more aggressive learning strategies. Combination of small firm size and global } \\
\text { potential of innovation causes radical transformations predicted in the born global model. }\end{array}$ \\
\hline 2004 & $\begin{array}{l}\text { Hashai \& Almor, } \\
2004\end{array}$ & $\begin{array}{l}53 \text { knowledge-intensive } \\
\text { born global firms, Israel }\end{array}$ & Quantitative & $\begin{array}{l}\text { Knowledge-intensive born globals follow internationalisation path sequentially: first - exporting, next - } \\
\text { greenfield marketing subsidiaries, and finally, engagement into mergers and acquisitions. }\end{array}$ \\
\hline 2004 & $\begin{array}{l}\text { Knight \& } \\
\text { Cavusgil, } 2004\end{array}$ & $\begin{array}{l}24 \text { interviews, } 203 \\
\text { manufacturing firms } \\
\text { surveys, USA }\end{array}$ & $\begin{array}{l}\text { Qualitative, } \\
\text { Quantitative }\end{array}$ & $\begin{array}{l}\text { International entrepreneurial orientation and international marketing orientation are the key } \\
\text { characteristics of born global companies which enforce rapid internationalisation. }\end{array}$ \\
\hline 2004 & $\begin{array}{l}\text { Knight et al., } \\
2004\end{array}$ & $\begin{array}{l}32 \text { case studies, } 292 \\
\text { surveys of born global } \\
\text { firms, Denmark, USA }\end{array}$ & $\begin{array}{l}\text { Qualitative, } \\
\text { Quantitative }\end{array}$ & $\begin{array}{l}\text { Born global international performance is enhanced by foreign customer focus and marketing } \\
\text { competences. }\end{array}$ \\
\hline 2004 & $\begin{array}{l}\text { Loane et al., } \\
2004\end{array}$ & $\begin{array}{l}8 \text { case studies of born } \\
\text { global firms, different } \\
\text { countries }\end{array}$ & Qualitative & $\begin{array}{l}\text { Rapid internationalisation is greatly enabled by internet. Competitive advantage is based on how } \\
\text { effectively firms integrate new technologies into their business model. }\end{array}$ \\
\hline 2004 & $\begin{array}{l}\text { Knight \& } \\
\text { Cavusgil, } 2004\end{array}$ & $\begin{array}{l}23 \text { small exporting firms, } \\
\text { USA }\end{array}$ & Quantitative & $\begin{array}{l}\text { Born global firms succeed because of the set of entrepreneurial characteristics and capabilities } \\
\text { possessed by managers. }\end{array}$ \\
\hline 2004 & Johnson, 2004 & $\begin{array}{l}\text { US and UK small high } \\
\text { technology international } \\
\text { start-ups }\end{array}$ & $\begin{array}{l}\text { Qualitative, } \\
\text { Quantitative }\end{array}$ & $\begin{array}{l}\text { The main factors pushing born globals to internationalise are the international vision of the founders, } \\
\text { their desire to be international market leaders, the identification of specific international opportunities } \\
\text { and the possession of international contacts. }\end{array}$ \\
\hline 2004 & $\begin{array}{l}\text { Gabrielson \& } \\
\text { Kirpalani, } 2004\end{array}$ & $\begin{array}{l}\text { Case studies of firms } \\
\text { from Israel and Finland } \\
\text { from similar industries }\end{array}$ & Qualitative & $\begin{array}{l}\text { Born globals must use existing channels and networks provided by multinational corporations. Those } \\
\text { channels provide learning, technology and rapid growth. }\end{array}$ \\
\hline 2004 & $\begin{array}{l}\text { Prashantham \& } \\
\text { Berry, } 2004\end{array}$ & & $\begin{array}{l}\text { Conceptual } \\
\text { paper }\end{array}$ & $\begin{array}{l}\text { There are four key influences on the internationalisation process of born globals - knowledge intensity, } \\
\text { small size of firms, the environment and the entrepreneur. }\end{array}$ \\
\hline
\end{tabular}




\begin{tabular}{|c|c|c|c|c|}
\hline 2004 & Moen et al., 2004 & $\begin{array}{l}5 \text { case studies of } \\
\text { software firms, Norway }\end{array}$ & Qualitative & $\begin{array}{l}\text { Firm's network relationships determine which entry forms to choose and which foreign markets to } \\
\text { enter. }\end{array}$ \\
\hline 2005 & Autio, 2005 & & $\begin{array}{l}\text { Conceptual } \\
\text { paper }\end{array}$ & $\begin{array}{l}\text { Advances in internationalisation theories and new directions for research in international } \\
\text { entrepreneurship are discussed. }\end{array}$ \\
\hline 2005 & $\begin{array}{l}\text { Jantunen et al., } \\
2005\end{array}$ & $\begin{array}{l}217 \text { firms in } \\
\text { manufacturing and } \\
\text { service sectors, Finland }\end{array}$ & Quantitative & $\begin{array}{l}\text { International performance is positively influenced not only by entrepreneurial orientation and by the } \\
\text { ability to use existing resources in order to exploit new opportunities. }\end{array}$ \\
\hline 2005 & $\begin{array}{l}\text { Jones \& Coviello, } \\
2005\end{array}$ & & $\begin{array}{l}\text { Conceptual } \\
\text { paper }\end{array}$ & $\begin{array}{l}\text { Providing foundation for entrepreneurial theory of internationalisation, where entrepreneurship and } \\
\text { internationalisation are seen as interdependent processes. }\end{array}$ \\
\hline 2005 & Rialp et al., 2005 & 38 studies & $\begin{array}{l}\text { Literature } \\
\text { review }\end{array}$ & The review of the international entrepreneurship literature from the past decade. \\
\hline 2006 & $\begin{array}{l}\text { Freeman et al., } \\
2006\end{array}$ & $\begin{array}{l}3 \text { small born global } \\
\text { exporters, Australia }\end{array}$ & Qualitative & $\begin{array}{l}\text { Among variables which are positively connected with rapid internationalisation are: personal networks, } \\
\text { strong commitment to the idea of internationalisation, unique technology, use of multiple entry modes } \\
\text { for different markets. }\end{array}$ \\
\hline 2006 & Larimo, 2006 & $\begin{array}{l}\text { Survey among Finnish } \\
\text { SMEs }\end{array}$ & Quantitative & $\begin{array}{l}\text { Export performance is positively impacted by firm size, product quality, international orientation and } \\
\text { market diversification. }\end{array}$ \\
\hline 2006 & $\begin{array}{l}\text { Sapienza et al., } \\
2006\end{array}$ & & $\begin{array}{l}\text { Conceptual } \\
\text { paper }\end{array}$ & $\begin{array}{l}\text { Building dynamic capabilities influence positively on firm's international performance. Factors } \\
\text { moderating relationship between capability development and survival and growth are identified. }\end{array}$ \\
\hline 2007 & Fan \& Phan, 2007 & $\begin{array}{l}135 \text { companies from } \\
\text { intra-european airline } \\
\text { industry }\end{array}$ & Quantitative & $\begin{array}{l}\text { The decision of internationalisation is influenced by external factors like size of the home market, } \\
\text { production capacity, cultural and economic forces. }\end{array}$ \\
\hline 2007 & $\begin{array}{l}\text { Fernhaber et al., } \\
2007\end{array}$ & & $\begin{array}{l}\text { Conceptual } \\
\text { paper }\end{array}$ & $\begin{array}{l}\text { The influence of industry structure on the new venture internationalisation is analysed. Positive } \\
\text { relationship between the knowledge intensity of an industry and a new firm internationalisation is } \\
\text { confirmed. }\end{array}$ \\
\hline 2007 & $\begin{array}{l}\text { Freeman \& } \\
\text { Cavusgil, } 2007\end{array}$ & $\begin{array}{l}12 \text { interviews with } \\
\text { exporters, Australia }\end{array}$ & Qualitative & $\begin{array}{l}\text { Entrepreneurial strategies that might be adopted for by small born global firms are: entrepreneurial } \\
\text { perception of opportunity-ridden environment, gradual network evolution, foreign markets network- } \\
\text { driven selection. }\end{array}$ \\
\hline
\end{tabular}




\begin{tabular}{|c|c|c|c|c|}
\hline 2007 & $\begin{array}{l}\text { Kuivalainen et al., } \\
2007\end{array}$ & $\begin{array}{l}185 \text { firms grown abroad } \\
\text { within the first three } \\
\text { years of operations, } \\
\text { Finland }\end{array}$ & Quantitative & $\begin{array}{l}\text { The "true born globals", characterised by entrepreneurial orientation, achieve international } \\
\text { performance significantly better than the "born internationals". }\end{array}$ \\
\hline 2007 & $\begin{array}{l}\text { Laanti et al., } \\
2007\end{array}$ & $\begin{array}{l}4 \text { wireless technology } \\
\text { born globals, Finland }\end{array}$ & Qualitative & $\begin{array}{l}\text { Conceptual framework is developed where resources and capabilities together with global } \\
\text { determinants and industry specific factors explain emergence of born global companies. }\end{array}$ \\
\hline 2007 & $\begin{array}{l}\text { Loane et al., } \\
2007\end{array}$ & $\begin{array}{l}57 \text { case studies, } \\
\text { Australia, Canada, } \\
\text { Ireland and New Zealand }\end{array}$ & $\begin{array}{l}\text { Qualitative, } \\
\text { Quantitative }\end{array}$ & $\begin{array}{l}\text { Top management teams create the core internal capabilities and address key resources or knowledge } \\
\text { gaps to expand international networks. }\end{array}$ \\
\hline 2007 & $\begin{array}{l}\text { Wright et al., } \\
2007\end{array}$ & & $\begin{array}{l}\text { Conceptual } \\
\text { paper }\end{array}$ & $\begin{array}{l}\text { Internationalisation is a dynamic activity and requires developing skills and gaining resources in the } \\
\text { process of international markets entry. }\end{array}$ \\
\hline 2007 & $\begin{array}{l}\text { Zucchella et al., } \\
2007\end{array}$ & 144 SMEs, Italy & Quantitative & $\begin{array}{l}\text { Individual variables which determine early international orientation are previous international } \\
\text { experience of an entrepreneur and foreign language knowledge. }\end{array}$ \\
\hline 2007 & $\begin{array}{l}\text { Gassmann et al., } \\
2007\end{array}$ & $\begin{array}{l}\text { Biotechnology SMEs, } \\
\text { Switzerland, Germany, } \\
\text { and Australia }\end{array}$ & Qualitative & $\begin{array}{l}\text { Born globals generate their competitive advantage based on dynamic capabilities, what enables them } \\
\text { to internationalise early and rapidly. }\end{array}$ \\
\hline 2007 & $\begin{array}{l}\text { Weerawardena } \\
\text { et al., } 2007\end{array}$ & & $\begin{array}{l}\text { Conceptual } \\
\text { paper }\end{array}$ & $\begin{array}{l}\text { Internationally-oriented entrepreneurs build a set of dynamic capabilities which help them to develop } \\
\text { cutting-edge knowledge intensive products and successfully enter international markets. }\end{array}$ \\
\hline 2008 & Rutihinda, 2008 & 64 exporters, Canada & Quantitative & $\begin{array}{l}\text { The research showed four major factors which explain internationalisation: international orientation of } \\
\text { the founder, globalisation of the firm's industry structure, established international networks and } \\
\text { foreign market potential. }\end{array}$ \\
\hline 2008 & $\begin{array}{l}\text { Gabrielson et al., } \\
2008\end{array}$ & $\begin{array}{l}8 \text { case studies of SMEs, } \\
\text { Greece, Norway, Finland, } \\
\text { Italy }\end{array}$ & Qualitative & $\begin{array}{l}\text { Selection of the right channels for rapid growth depends on specific characteristics of the firm and its } \\
\text { founder, the product and innovation, and the networking approach. }\end{array}$ \\
\hline 2008 & Bhowmick, 2008 & 4 case studies & Qualitative & $\begin{array}{l}\text { Internationalisation process is a combination of enactment and effectuation. Enactment concept is } \\
\text { quite similar to effectuation. It means that the entrepreneurs, being a part of the situation they face, } \\
\text { act without full knowledge of the situation, though both the situation and the decisions are often } \\
\text { rationalized in retrospect. }\end{array}$ \\
\hline 2008 & $\begin{array}{l}\text { Mainela \& } \\
\text { Puhakka, } 2008\end{array}$ & $\begin{array}{l}1 \text { case study of IJV, } \\
\text { Poland }\end{array}$ & Qualitative & $\begin{array}{l}\text { International entrepreneurship is a complicated process which requires a set of means which are } \\
\text { effectuation logic, proactiveness and partnering strategies. }\end{array}$ \\
\hline
\end{tabular}




\begin{tabular}{|c|c|c|c|c|}
\hline 2009 & $\begin{array}{l}\text { Zhang et al., } \\
2009\end{array}$ & $\begin{array}{l}148 \text { manufacturing firms, } \\
\text { China }\end{array}$ & Quantitative & $\begin{array}{l}\text { Born global firms are different from traditional firms along three dimensions: international learning } \\
\text { capability, international networking capability and international experience. }\end{array}$ \\
\hline 2009 & $\begin{array}{l}\text { Brennan \& } \\
\text { Garvey, } 2009\end{array}$ & & $\begin{array}{l}\text { Literature } \\
\text { review }\end{array}$ & $\begin{array}{l}\text { Article presents a synthesis on born global phenomenon in the framework of new perspective on the } \\
\text { role of knowledge. Knowledge intensity and internationalisation knowledge accumulation influence the } \\
\text { pace and pattern of firm internationalisation. }\end{array}$ \\
\hline 2009 & Lopez et al., 2009 & $\begin{array}{l}40 \text { software companies, } \\
\text { Costa Rica }\end{array}$ & Qualitative & $\begin{array}{l}\text { The majority of surveyed firms turned out to be "born regionals", as they followed gradual } \\
\text { internationalisation approach. }\end{array}$ \\
\hline 2010 & $\begin{array}{l}\text { Schweizer et al., } \\
2010\end{array}$ & 1 case study, Sweden & $\begin{array}{l}\text { Conceptual } \\
\text { paper }\end{array}$ & $\begin{array}{l}\text { Authors updated their conceptual model from } 1977 \text { and } 2009 \text { and included entrepreneurial aspects, } \\
\text { like effectuation principle. Their updated model includes "exploiting contingencies" variable leading to } \\
\text { progress in the internationalisation process. Authors agree that effectuation logic can strongly } \\
\text { contribute to internationalisation of firms. }\end{array}$ \\
\hline 2011 & \begin{tabular}{|l|} 
Prange \& \\
Verdier, 2011
\end{tabular} & & $\begin{array}{l}\text { Literature } \\
\text { review }\end{array}$ & $\begin{array}{l}\text { Authors investigate the concept of dynamic capabilities which affects the pace of internationalisation. } \\
\text { Such capabilities are divided into two separate classes of explorative and exploitative capabilities. The } \\
\text { new notion of third-order capabilities is introduced. }\end{array}$ \\
\hline 2012 & $\begin{array}{l}\text { Roudini \& } \\
\text { Osman, } 2012\end{array}$ & & $\begin{array}{l}\text { Conceptual } \\
\text { paper }\end{array}$ & $\begin{array}{l}\text { International entrepreneurial capability consists of several dimensions - international networking } \\
\text { capability, international marketing capability, innovation and risk-taking capability, international } \\
\text { learning capability and international experience. }\end{array}$ \\
\hline 2012 & $\begin{array}{l}\text { Kuivalainen et al., } \\
2012\end{array}$ & & $\begin{array}{l}\text { Literature } \\
\text { review }\end{array}$ & $\begin{array}{l}\text { Antecedents of internationalisation on the managerial level are mindset of an entrepreneur, his } \\
\text { experience and entrepreneurial orientation. Networks and knowledge are included into the model as } \\
\text { well on the firm level. }\end{array}$ \\
\hline 2012 & $\begin{array}{l}\text { Harms \& Schiele, } \\
2012\end{array}$ & $\begin{array}{l}65 \text { rapidly growing SMEs, } \\
\text { Germany }\end{array}$ & Quantitative & $\begin{array}{l}\text { Entrepreneurs tend to apply effectuation rather than causation. The importance of the individual level } \\
\text { of analysis in international entrepreneurship research is emphasised. }\end{array}$ \\
\hline 2012 & $\begin{array}{l}\text { Gabrielsson et } \\
\text { al., } 2012\end{array}$ & $\begin{array}{l}261 \text { firms, Finland, } \\
\text { Sweden }\end{array}$ & Quantitative & $\begin{array}{l}\text { The research investigates marketing strategies for foreign expansion of companies originating in } \\
\text { SMOPECs. }\end{array}$ \\
\hline
\end{tabular}




\begin{tabular}{|l|l|l|l|l|}
\hline 2013 & $\begin{array}{l}\text { Laurell et al., } \\
2013\end{array}$ & $\begin{array}{l}\text { Case study of the new } \\
\text { venture from the life } \\
\text { sciences industry, } \\
\text { Sweden }\end{array}$ & Qualitative & $\begin{array}{l}\text { Some factors in the industry context affect internationalisation process, especially entrepreneurs and } \\
\text { their networks. }\end{array}$ \\
\hline 2014 & $\begin{array}{l}\text { Sarasvathy et al., } \\
2014\end{array}$ & 1 case study, India & Qualitative & $\begin{array}{l}\text { Effectual approach can resolve conflicts and knowledge gaps in two reviews of international } \\
\text { entrepreneurship. Authors offer four possibilities for future research at the intersection of } \\
\text { international entrepreneurship and effectuation research. }\end{array}$ \\
\hline 2014 & $\begin{array}{l}\text { Crick \& Crick, } \\
2014\end{array}$ & 16 high-tech SMEs, UK & Qualitative & $\begin{array}{l}\text { The study confirms the use of both effectuation and causation logic within the high-tech SMEs. } \\
\text { Opportunities in the international niche markets and manager's experience and networks are } \\
\text { confirmed to affect internationalisation strategies. }\end{array}$ \\
\hline 2015 & $\begin{array}{l}\text { Knight \& Liesh, } \\
2015\end{array}$ & $\begin{array}{l}\text { Conceptual } \\
\text { paper }\end{array}$ & $\begin{array}{l}\text { The stage internationalisation models of multinational enterprises are compared to the rapid } \\
\text { internationalisation models of born global firms. }\end{array}$ \\
\hline 2015 & $\begin{array}{l}\text { Galkina \& Chetty, } \\
2015\end{array}$ & 7 case studies, Finland & Qualitative & $\begin{array}{l}\text { International entrepreneurs network with interested partners, instead of carefully selecting } \\
\text { international partners. }\end{array}$ \\
\hline 2015 & $\begin{array}{l}\text { Pellegrino \& } \\
\text { McNaughton, } \\
2015\end{array}$ & 4 INVs, New Zealand & Qualitative & $\begin{array}{l}\text { Internationalisation strategy of INVs evolves during internationalisation process. Learning during } \\
\text { internationalisation comes from interactions among learning, the knowledge learned, components of } \\
\text { internationalisation strategy, resource constraints, characteristics of industry/product. }\end{array}$ \\
\hline
\end{tabular}

Source: own study. 